\title{
Why in Favor of Tawarruq not Bai' Al-Inah in Personal Financing Product?
}

\author{
Azahari Jamaludin ${ }^{1}$ \\ ${ }^{1}$ IQRA Business School, Geomatika University College, Kuala Lumpur, Malaysia \\ Correspondence: IQRA Business School, Geomatika University College, Kuala Lumpur, Malaysia, E-mail: \\ drazahari@geomatika.edu.my, Tel: +60-3-4252 4576
}

Received: April 12, 2018

Accepted: April 15, 2018

Online Published: April 20, 2018

\begin{abstract}
In view of the limited of study with regards to the concept of Bai ${ }^{\text {ie }} \mathrm{Al}$-Inah and Tawwaruq on personal financing, the findings from this study would provide evidence on the understanding of the two concepts, and to determine whether there exists elements of Riba or otherwise in the present medium of personal financing. In addition, the findings of this study can provide a premise whether Tawwaruq is a solution to Baie Al-Inah in personal financing offered by Islamic banksand financial institutions or otherwise. Further, the outcomes may also have some policy implications whereby the policy made can suggest the adoption of Tawwaruq or Baiec Al-Inah as a best solution to Riba-based personal financing.
\end{abstract}

Keywords: Islamic Banking System; Tawarruq; Baie Al-Inah; Personal Financing

\section{Introduction}

Today, the number of Islamic banks and the financial institutions are increasing. New Islamic banks with large amount of capital are being set-up. Conventional banks are opening Islamic subsidiaries for the operation of Islamic banking. Even the non-Muslim financial institutions are entering the field and trying to complement each other"s businesses in order to attract as many Muslim as well as non-Muslim customers. Therefore, it seems that the size of capital of Islamic banking will be multiplied in the next decade and the operations of Islamic banks are expected to cover a large area of financial transaction of the world (Wafa, Nasri, \&Hazim, 2003; Usmani, 2002). Although there are differences between Islamic banking system and conventional banking system; there are some similarities between the two. For example, an Islamic bank conducts its activities in accordance to the Shariah principle that strictly prohibited any payment or receipt of interest (Riba). Additionally, the Islamic bank can also offer products and services which are similar to those offered by a conventional bank (Haron, 2005; Yakcop, 1996). The difference mainly lies in the manner the banking transactions are conducted and the way money is mobilized and recorded. Islamic banks are offering a wide range of Islamic financing products and one of which is personal financing. While personal loan in conventional banks is interest based, personal financing in Islamic banking adapts the principle of Bai'Al-Inah (Sabran, 2000; Shamsuddin, 1995).

According to SaifulAzhar and Azizi (2003) Bai'Al-Inah is permitted by the Shafiee School of Fiqhandit is widely used in many banking facilities such as personal financing. With global markets, the requirement for the product to be globally accepted is no longer an option but a must. It is worth to mention that international Islamic portfolios fund managers are generally advised by Middle-Eastern Muslim Jurists (Fuqaha') most of whom belong to the Maliki, Hanbali, and Hanafi schools of Fiqh. Thus, it is critical that Islamic financial instruments are designed to attract these investors as well. Insisting on a Shariah standard based on one school of fiqh alone may not be of interest as this may isolate the respective country from global Islamic finance. According to Ali (2006), Tawarruq 
is the sale that is comprehensive as it examines the kinds and forms and it current practiced by Islamic and commercial banks and financial institutions. This sale has become one of the important transactions used by banks to enable their customers to get liquidity.

\section{Strategic Issues}

Islamic Muamalat does not only provide different varieties of banking products but also provides new business environment to customers. However, to what extent does this product will be able to contribute to the growth in Islamic banking system? Since the study of personal loan has evolved extensively in conventional banking, it is of great interest to study the personal financing involving Islamic model.

The problem is inherent in the present personal financing offered by Islamic banks in perplexity surrounding the concept of Bai'Al-Inah. Certain group of scholar's opinion is that personal financing based on Bai'Al-Inah concept is still having the element of Riba, while certain scholars approve the usage of Bai'Al-Inah. This question motivates the researcher to find out the reasons behind these two different opinions. In addition, another emerging thought is Tawarruq is a better model than Bai'Al-Inah in personal financing. Hence, this study also aims to find out the issue of Tawarruq as personal financing.

\section{Shariah Rules in Islamic Banking System}

According to the Central Bank of Malaysia (2005), Islamic banking has the same objectives as conventional banking except that the former operates based on Shariah principles known as Fiqh Al-Muamalat (Islamic rules in business transaction). The basic principle of Islamicbanking is profit and loss sharing and prohibition of Riba ${ }^{\text {ee }}$. Among the model commonly used in Islamic banking are profit and loss sharing (Mudharabah), agreement sell and buy back (Bai'Al-Inah), deferred sale (Bai' BithamanAjil), joint venture (Musharakah), costplus (Murabahah), and leasing (Ijarah).

In Islamic banking operations the Islamic laws are very important. For instant, personal financing is not referred to as interest charged but it is referred to as business transaction and goods trading serve as a basis for financing arrangement. On the other hand, the conventional banking system which is interest based, the debtor has to pay the principal plus the interest for any loan applied (Azhar\&Sanusi, 2003). This problem of interest has been studied for sometimes and there are a lot of solutions to choose from which are permissible by Islamiclaws. For example, Bai' Al-Inah concept has been introduced to overcome the interest based personal loan. Besides Bai' Al-Inah, Tawwaruq is relatively new and only a few Islamic financial institutions have implemented Tawwaruq as their personal financing product (Azahari, 2013; Mohd Farihal, 2007).

\section{A Review on Riba}

According to Muhammad Ayub (2007), effort has been made to ascertain what constitutes Riba. Any increase over the principal amount of a loan or debt against nothing but time is Riba. As a logical corollary to the prohibition of Riba, the Shariah has prohibited all benefits accruing to a person without any labor, risk or expertise. Any person who wishes to earn profit on his monetary investment must bear the loss or damages accruing to the business where his money capital has been used. A number of verses of the Holy Qur'an expressly prohibit Riba. For example, Surah al-Baqarah, verses 276-279:

"Allah deprives Riba of all blessing but blesses charity; He loves not the ungrateful sinner."

"O, believers, fear Allah, and give up what is still due to you from Riba if you are true believers." (278) 
"If you do not do so, then take notice of war from Allah and His Messenger. But, if you repent, you can have your principal. Neither should you commit injustice nor should you be subjected to it." (279)

Additionally, the following Hadiths of the holy Prophet Muhammad (pbuh) reiterate the prohibition of Riba: From Jabir (Gbpwh): "The Prophet Muhammad(pbuh) cursed the receiver and the payer of interest, the one who records it and the witnesses to the transaction and said: They are all alike [in guilt]."

From Anas ibn Malik (Gbpwh): “The Prophet Muhammad(pbuh) said: „When one of you grants a loan and the borrower offers him a dish, he should not accept it; and if the borrower offers a ride on an animal, he should not ride, unless the two of them have been previously accustomed to exchanging such favors mutually."

Riba means extra and there are two major types of Riba. The first type of Riba is RibaDuyun which can be further sub-divided into RibaQardh and RibaJahiliyah. The second type of Riba is RibaBuyu which can be subdivided into RibaFadhl and RibaNasiah (Muhammad Ayub, 2007).

\subsection{Types of Riba \\ - Riba Duyun}

RibaDuyun is the extra amount of money over and above the principal of the loan either, imposed by the lender upon the borrower in the contract or promised by the borrower in the contract. RibaDuyun can be sub-divided into RibaQardh and RibaJahiliyah. RibaQardh is effective from the beginning of the transactions on the other hand RibaJahiliyah is only effective after the payment is default and there is noRiba at the beginning of the transactions. This type of Riba occur out of an exchange between two ribawi materials of the same kind where the necessary rule(s) are not observed. There is no Riba in trading transactions where a ribawi material is exchanged with a non-ribawi material like money with a car; or a non-ribawi material is exchanged with another non-ribawi material like rubber with a refrigerator.

- Riba Buyue

RibaBuyu' can be sub-divided in two types, RibaFadhl and RibaNasiah. RibaFadhl i.e. the ribawimaterials (of the same kind) exchanged is of different weights, measurements or numbers and they are exchanged at the same time. On the other hand, RibaNasiah or RibaYad i.e. the ribawi materials exchanged are of equal weights, measurements or numbers but payment of the price and delivery of the goods are made at two different times.

Islamic banking does not give out loans. Therefore, Riba out of lending and borrowing does not arise. To avoid involvement with Riba in trading transactions, Islamic banking must pay proper attention to the requirement that the buying and selling of the following matters must be on cash basis:

a. Gold in treasury functions for liquidity; and

b. Silver in treasury functions for liquidity, and currencies, the currency of each country being considered as a kind, for hedging and payments of imports.

Principle of jurisprudence is a principle recognized by Shariah. It is made by scholars to facilitate the process referring to the fiqh problems based on Shariahprinciple (Abu Ghuddah 1992:129).

\section{A Review on Bai'Al-Inah and Tawwaruq Practice}

Bai'Al-Inah is an act of selling subject matter and then repurchase it back with lower price (Ibn Qudamah 1408H: 26). Although it appears that a consensus on Bai'Al-Inah has been made the view of Shariah scholars do differ, especially when the requirement for the product to be globally viable and accepted. This is due to fund managers of international Islamic portfolios are generally advised by Middle-Eastern Muslim jurists (fuqaha ${ }^{\circ}$ ), most of whom belonging to Maliki, Hanbali and Hanafi schools of fiqh. Therefore, it is important that Islamic financial 
instruments (such as Tawarruq) are designed to attract these investors as well. Insisting on a Shariah standard based on one school of fiqh alone may not be good as this may isolatedthe respective nation (i.e. Malaysia) from global Islamic finance (SaifulAzhar and Azizi, 2003).

\subsection{The Practice of Bai' Al-Inah}

According to Azahari (2013), Bai' Al-Inah is defined as a sale with immediate repurchase. It involved the sale and repurchase transaction of an asset by a seller (Islamic bank). In the first transaction, a seller sells his or her assets to a buyer on credit (deferred price). Subsequently, in the second transaction, the buyer resells the same assets back to the seller on cash term at a lower price than the deferred price. Therefore, the transaction amounted to a loan. The difference between the two prices represents the interest (riba). Such contract was evolved in the early period of Islam and it exists for the fundamental reason that a loan for interest is forbidden because it is equivalent to riba (usury). In this contract, there is an economic interest for both parties (lender and borrower), which at the same time circumvents the prohibition of Riba or usury.

The personal financing used by Islamic bank based on repurchase or Bai'Al-Inah. A Murabaha financing can be converted into Bai' Al-Inah if the identity of the vendor is not different from its client, when the bank purchases a commodity from its client on a spot basis and sells it back to the client at a cost-plus price and on a differed basis. The rate of profit in this case is indistinguishable from prohibited riba in a conventional personal loan. For example, when a seller (Islamic bank) sells the asset to a customer on a deferred basis and later the seller will repurchase the same asset on a cash basis at a lower price than the deferred price (Mohd Farihal, 2007). The following Figure 1 depicted the Bai' Al-Inah personal financing modus operandi.

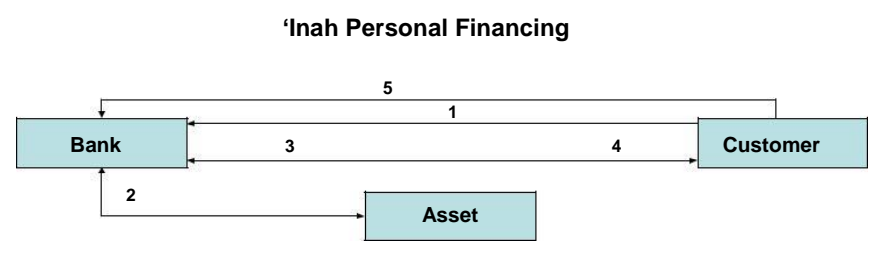

Figure 1: Bai' Al-Inah Personal Financing Modus Operandi

The Bai' Al-Inah personal financing modus operandi:

- The customer approaches the Islamic bank for financing.

- The bank identifies the asset that will be traded under Bai'Al-Inah contract.

- The bank and customer sign a first sales and purchase contract where the Islamic bank sells the asset at a selling price (financing amount plus profit margin) on deferred terms and the ownership is transferred to the customer.

- The bank and the customer sign a second sales and purchase contract where the bank buys back the asset sold to the customer at a cost price and pays on cash basis.

- The customer begins to pay his installment to the bank (Azahari, 2013; ISRA, 2011). 
Shariah View on Bai Al-Inah Transaction

According to Mohd Farihal (2007), there are differences in scholar"s opinion on ascertaining the hukmon the Bai'Al-Inahmodel in Muamalat transaction. Here, the issue is how Shariah views such contract and what is the hukm to solve the implementation of Bai'Al-Inahmodel in Islamic personal financing?

According to Shafie $i$ and Ibn Hazm, such sales are to be allowed, but abhorrent, with certain conditions and do not involve Riba, uncertainties and gambling. Their reason is that Bai'Al-Inah contract has satisfied all the requirement of a valid contract. The intention of the contracting parties has no effect on the validity of the sale. The intention is not considered since there is no means to know it, unless intention is expressed explicitly (Abu Ishaq). In the Shafieci and the Zahir schools of fiqh only external intention of the contracting parties is to be considered. Thus, Bai'Al-Inah is valid on the basis of the verse: "Allah has allowed the sale and purchase and has forbidden the interest." They do not address the succession of two contracts of sale as sufficient evidence to prove the existence of a ribawi intention (Ibn Hazm). In addition, Abu Yusuf from Hanafi School considered this sale as valid without abhorrence, and Muhammad ibn al-Hassan al-Shabani had a slightly different view. He perceived this sale as valid with abhorrence.

However, Maliki, Hanafi, Hanbali, and ibnuTaimiyah declare that the contract is void, haram and sinful, for such a transaction is Riba or smacks of Riba(shubahat). They argue that the form of the contracts of sale in "Bai'", are nothing but a legal device or a legal fiction (hilah) to legalize what is intrinsically illegal by Shariah, as they classify "Bai", in the essence, a loan with interest. They base their objections to the validity of "Bai", on the following.

- It is an uncalled for hilah as mentioned above.

- The presumed wrongful intention (niat) to commit Riba transaction, in line with the hadith which says "all actions are judged by intention."

- The reported of famous incident narrated by Imam ad-Daruquthni and al- Bayhaqi from Abu Ishaq, from his wife Aliyyah discovered that it was from SayidatinaAisyah, UmmulMukminin together with Umm WaladZayd ibn Arqamand another women. Umm Walad Zaid said, I used to sell slaves to Zaid costing 800 dirhams with deferred payment and I bought back (the slaves) at the price of 600 dirhams on cash. SayidatinaAisyah said, it is not a good way to sell and buy. Tell Zaid that he is cancelling his reward of Jihad and Hajj along with Rasulullah unless Zaid repents!

The above view is based on the report of an incident between Zaid Abu Arqam and SayidatinaAisyah. Jurists supporting the Bai'Al-Inah sale also apply analogy (qiyas) on the means/expedients (dhara' $i$ ) but this is prohibited and constitutes the motive of the contract. They concluded that the Bai'Al-Inah sale is a mechanism to legalize Riba. Anything that can be used as a means to commit a prohibited is prohibited (Mohd Farihal, 2007).

Further, Abu Hanifah claims that this contract is void (batil) if it does not involve a third party, who either deals with the original seller or buyer. However, Abu Hanifah in this case appears to have changed his previous opinion in which he concluded that the Bai'Al-Inah sale is sahih.

Based on the above discussion, we can conclude that the objection on the validity of Bai'Al-Inah is based on the following reason:

- It is a legal device (Hilah).

- The presumed wrongful intention to commit Riba transaction. This is explained by the hadith which say “all actions are judged by intention": Zaid ibn Arqam.

- The reported opinion of Aishah against Zaid ibn Arqam.

- The reported sahihhadith narrated by Ibnu Umar. 
However, Al-Shafie rejected the hadith regarding Zaid ibn Arqam and Aishah, saying that the hadith is not established (Thabit) for the following reasons.

Aishah"s condemnation of the Bai'Al-Inah sale is based on the view that the payment on the sale is deferred into some unknown or unspecified period. Sale with deferment in payment is not valid.The incident involved two companions and if there are disagreements between the companions, Shafie methodology is to take the opinion of whom we can use analogy (qiyas) with. In this case it is on Zaid said. In other word, while it is clear that Zaid acted contrary to the meaning of the hadith, this does prove that the companions themselves were not of the same opinion. When this happens, analogy (qiyas) is applied (ISRA, 2011; Muhammad Ayub, 2007; Mohd Farihal, 2007).

\subsection{The Practice of Tawarruq}

According to AAOIFI Shariah Standard (2006), Tawarruq is the purchase of a commodity on deferred payment basis by way of either direct sale or Murabaha. The commodity is then sold for cash to a party other than the original seller. Further, Engku Rabiah claims that Tawarruq has been generally used to refer to an agreement whereby a person who was in need of cash bought some goods for deferred payment and then sold the same goods to another party (not the original seller) for cash payment at a lower price.

According to ISRA (2011), Tawarruq is a Shariah compliant financing method, with which you can raise financing through buying installments in a local commodity, owned by the bank. The applicant then authorizes the bank to sell his share in this commodity on his behalf to a third party for cash and then deposit the proceeds into his account. Further, Tawarruq can be defined as an arrangement that involves a purchase of an asset based on musawamah or murabahah and a subsequent sale of the same asset to a third party in order to get cash money. For example, one party buys a commodity on credit term at a mark-up price and sells the same commodity at a lower price to a third party to get cash. The end result of this transaction is that, the customer obtaining cash to be used for his or her personal needs or business (ISRA, 2011). The following Figure 2 depicted the Tawwaruq personal financing modus operandi.

\section{Tawarruq Personal Financing}

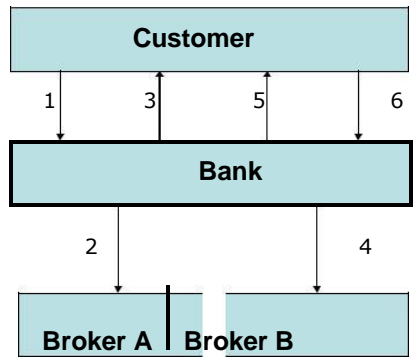

Figure 2:Tawarruq Personal Financing Modus Operandi

The Tawarruq personal financing modus operandi:

- The customer and the bank (Islamic bank) enter into an arrangement where the customer promises to buy a commodity or asset from the bank. The customer at the same time appoints the bank as his agent to sell the said commodity or asset.

- The bank buys a commodity or asset from Broker A on a spot basis. 
- The bank sells the same commodity or asset to the customer on deferred basis at cost plus profit.

- The bank as an agent to the customer sells the same commodity or asset to Broker B on a spot basis.

- The bank pays the customer the sale proceeds in a lump sum basis.

- The customer pays the bank the purchase price of the commodity or asset on a deferred installment basis (Azahari, 2013; ISRA, 2011).

\section{Shariah View on Tawarruq Transaction}

Here, the issue of concerns is how Shariah views such contract Tawarruq. Differences of scholar opinion on ascertaining the hukm on the concept of Tawarruq in transaction are as follow.

- The Jumhur, Hanabilahand Shafie" View: According to Al-Zarkashiyy (1982), Tawarruq is generally permissible. Their reason: "Allah has allowed the sale and purchase and has forbidden the interest."

Sell subject matter to third party

The Prophet Muhammad (pbuh) said in work: "The sale of large amount of dirham and sale of dirham janib have no element of TawarruqRiba. It is a sale and purchase transaction."

The Ibn Taymiyyah (2005) and Ibn Qayyim (1973) view: Tawarruq is generally disallowed. In fact, they are strongly against the practice and consider it as fraud against Allah and Shariah. Ibn Taymiyyah"s reason: "Verily, the Prophet Muhammad (pbuh) has forbidden selling while in urgent condition."

\section{Conclusion}

Both Tawarruq and Bai' Al-Inahare interest free (Riba free) models as prescribed in the application of Bai'Al-Inah principle and Tawarruqprinciple. Islamic personal financing uses the method that is accepted by Shariah Advisory Board (SAB). There are Islamic scholars who support the practice of Bai' Al-Inah and Tawarruq in Islamic personal financing as the best alternative for avoiding Riba.The transaction using Bai'Al-Inah and Tawarruq has several differences. The Bai'Al-Inah involves two (2) parties in completing each transaction whereas the Tawarruq involves three (3) parties. The purpose of Bai' Al-Inah and Tawarruq are the same but the way the Hilah is practices is different. Bai'Al-Inah has many Hilah (the way the transaction performed is like buy and selling transaction although the purpose is for money lending). On the other hand, Tawarruqhas less Hilah. Based on the model and study done by Azahari (2013) and Mohd Farihal (2007), Tawarruq is really needed and should be introduced into themarket such as Malaysia, as Tawarruq promotes a better Islamic banking practice.

\section{References}

AAOIFI Shariah Standard (2006). Retrieved on 28.08.2013: http://www.aaoifi.com/aaoifi/default.aspx Abu Ghuddah, A.S. (1992:129). "Buhus fi al-Fiqh Al-Tibbiwa al-SihhatAlnafsiyyah min Mansur Islami." Abu Ishaq al-Shatibi, al-Muwafaqat fi usul al-Shari'ah, Vol. 7, pg: 435-436.Kaherah: Dar Ibn „Affan AlZarkashiyy, B.a.-D.M.b. (1982). “Al-Manthur fi Qawaid.”Wazarah al-awqaf'.

Ali, A.P.D.E.R.A.b.E. (2006). Tawarruq vis-à-vis commodity Murabahah. Centre for Research and Training, PWTC, Kuala Lumpur.

Azahari, J. (2013). TawarruqAnd Bai' Al-Inah As A Solution To Riba-Based Personal Financing Product.Professional Practice Paper.Kuala Lumpur: INCEIF.

Azhar, S. \& M.M. Sanusi (2003). "The Application of Bay"Inah and Bay Al" Dayn in Malaysia Islamic Bonds, an Islamic Analysis." International Journal of Islamic Financial Services 1(2).

Bank Negara Malaysia (BNM) (2005). "Ringkasan Keputusan Majlis Penasihat Kebangsaan untuk Perbankan Islam dan Takaful. ’JabatanPerbankan Islam dan Takaful.

Haron, S. (2005). “SistemKewangandanPerbankan Islam. ”Kuala Lumpur Business School Sdn. Bhd.Ibn Hazm, Al-Mahalla bi Al-Athar, Vol. 7, p: 549 in ISRA. 
www.cribfb.com/journal/index.php/ijibfr $\quad$ International Journal of Islamic Banking and Finance Research $\quad$ Vol. 2, No. 1; 2018

Ibn QayyimaJ, M I A B aZ (1973). I'lam al Muwaqqi in an Rabb al-Alamin, Taha „Abdul-Ra“ufSa“ad (editor), Beirut: Dar al-Jil.

IbnQudamah, (1408H: 26). “Al-MughniSyarah al-kabir.” Dar AlamulKutub.

Ibn Taymiyyah, A aA A i AH (2005). Majmu al-Fatawa, third edition, Anwar al-Baz and Amir al-Jazzar (editor), Jeddah: Dar al-Wafa.

International Sharieah Research Academy for Islamic Finance (ISRA) (2011).Islamic Financial System: Principles \& Operations. Kuala Lumpur, Malaysia: ISRA.

Mohd Farihal, O. (2007). Bai al-Inah and Tawrruq as a Solution to Interest-Based Personal Financing Facility.Sintok, Kedah: Universiti Utara Malaysia.

Muhammad Ayub (2007). Understanding Islamic Finance. West Sussex, England: John Wiley \& Sons Ltd.

Sabran, O. (2000). “UrusNiaga Al-Bai BithamanAjil: DalamMekanismePembiayaanTanpaRiba, SkudaiJohor: UniversitiTeknologi Malaysia.

SaifulAzharRosly \& Azizi Che Semanb (2003). Juristic Viewpoints On Bay“e Al-Inah In MALAYSIA: A SURVEY, IIUM Journal of Economics and Management, vol. 11, issue 1, pages 87-112

Shamsuddin, A.K. (1995). “Riba’ AlternatifnyaDalamSistem Bank Islam.” Kuala Lumpur: Dewan Bahasa danPustaka.

Usmani, M.T. (2002). “An Introduction to Islamic Finance.” The Hague: Klewer Law International.

Syed Mohd. GhazaliWafa, S. A. W., Muhammad Nasri, M. H. \& Mohd.Hizam, H. (2009). Pengantarperniagaan Islam. Selangor: Prentice Hall, Pearson Malaysia Sdn. Bhd.

Yakcop, N.M. (1996). “Teori, AmalandanProspekSistemKewangan Islam di Malaysia. ”Kuala Lumpur:Utusan Publications \& Distributors Sdn. Bhd.

\section{Copyrights}

Copyright for this article is retained by the author(s), with first publication rights granted to the journal.

This is an open-access article distributed under the terms and conditions of the Creative Commons Attribution license (http://creativecommons.org/licenses/by/4.0/). 